\title{
Clinical Trial Insurance Documentation
}

National Cancer Institute

\section{Source}

National Cancer Institute. Clinical Trial Insurance Documentation. NCI Thesaurus. Code C115651.

Records detailing the availability of compensation to a trial subject for injuries related to their participation in the trial. 